\title{
Effects of re-immunization of heifers against inhibin on hormonal profiles and ovulation rate
}

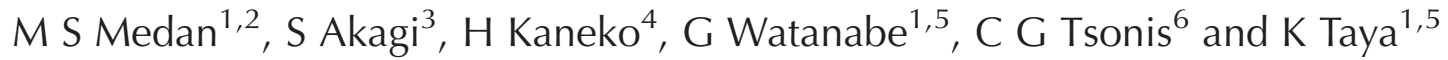 \\ ${ }^{1}$ Laboratory of Veterinary Physiology, Department of Veterinary Medicine, Faculty of Agriculture, Tokyo University \\ of Agriculture and Technology, Tokyo 183-8509, Japan, ${ }^{2}$ Department of Theriogenology, Faculty of Veterinary \\ Medicine, Suez Canal University, Ismailia, Egypt, ${ }^{3}$ Reproductive Cell Biology, Department of Animal Breeding and \\ Reproduction, National Institute of Livestock and Grassland Science, Ibaraki 305-0901, Japan, ${ }^{4}$ Department of \\ Genetic Resources II, National Institute of Agrobiological Resources, Tsukuba, Ibaraki 305, Japan, ${ }^{5}$ Department of \\ Basic Veterinary Science, The United Graduate School of Veterinary Science, Gifu University, Gifu, Japan and \\ ${ }^{6}$ Biotech Australia Pty Ltd, PO Box 20, East Roseville, NSW 2460, Australia
}

Correspondence should be addressed to Kazuyoshi Taya; Email: taya@cc.tuat.ac.jp

\begin{abstract}
To study the effect of re-immunization against inhibin on ovarian response and hormonal profiles, Japanese beef heifers $(n=5)$ were re-immunized three times with inhibin vaccine (recombinant ovine inhibin $\alpha$-subunit in oil emulsion, $125 \mu \mathrm{g} \mathrm{ml}{ }^{-1}$ ) one year after the primary immunization. Control heifers $(n=5)$ were injected with placebo (Montanide: Marcol adjuvant alone). Oestrous cycles were synchronized by using prostaglandin $\mathrm{F}_{2 \alpha}\left(\mathrm{PGF}_{2 \alpha}\right)$ and ovarian response was monitored daily by ultrasonography. Blood samples were collected by jugular venipuncture for assessment of hormonal levels and inhibin antibody titres. In contrast to controls, inhibin re-immunized heifers generated antibodies against inhibin rapidly reaching a peak level 9 days after the first booster injection. The mean concentrations of FSH in re-immunized cows increased significantly in comparison with controls. In addition, there was a significant increase in oestradiol-17 $\beta$ and progesterone levels in re-immunized cows compared with controls. Inhibin re-immunized heifers had a significant increase in small ( $\geq 4<7$ mm), medium $(\geq 7<10 \mathrm{~mm})$ and large ( $\geq 10 \mathrm{~mm}$ in diameter) sized follicles. Moreover, the mean ovulation rate was $5.0 \pm 1.1$ after the third booster injection in re-immunized heifers compared with control heifers (single ovulation). These results clearly demonstrate that re-immunization of inhibin can be used to enhance ovarian follicular development and ovulation rate. Furthermore, the great number of follicles is a potential source of oocytes that could be harvested for in vitro fertilization and embryo transfer programmes.

Reproduction (2004) 128 475-482
\end{abstract}

\section{Introduction}

Previous studies support the importance of inhibins in the regulation of pituitary secretions of follicle-stimulating hormone $(\mathrm{FSH})$ and negative correlation between FSH and inhibins has been reported (Beard et al. 1990, Kaneko et al. 1993a,b, 1995b, Tilbrook et al. 1993, Kishi et al. 1997, Ramaswamy et al. 1998, Araki et al. 2000). In domestic animals, induction of multiple ovulations is possible by administering exogenous gonadotrophins or by removing the inhibitory action of ovarian hormones on endogenous gonadotrophin release by the hypothalamus-pituitary axis. The use of a combination of equine chorionic gonadotrophin (eCG) and human chorionic gonadotrophin (hCG) has been widely used to induce superovulation. However, repeated eCG treatments lead to ovarian refractoriness and have clear negative effects on reproduction (Bavister et al. 1986, Swanson et al. 1995, Roy et al. 1999).

In trials to develop alternative methods for superovulation in domestic animals, passive (Campbell \& Scaramuzzi 1995, Kaneko et al. 1995b, Kusina et al. 1995, Akagi et al. 1997, Nambo et al. 1998, Medan et al. 2003a) and active (Fray et al. 1994, Glencross et al. 1994, Akagi et al. 2002, Medan et al. 2003b) immunizations against inhibins were used.

Although it is well established that passive or active immunization against inhibin neutralized endogenous inhibins and increased ovulation rate, further studies are needed to confirm the effect of re-immunization against inhibin on hormonal profile and ovulation rate. Therefore, the objective of the present study was to determine the effect of re-immunization of heifers with inhibin vaccine, 1 year after primary immunization, on gonadotrophins, 
oestradiol and progesterone secretions, the number of follicles and ovulation rate.

\section{Materials and Methods}

\section{Experimental design}

This study was carried out on ten Japanese beef heifers weighing $455-510 \mathrm{~kg}$, their ages ranged from 5 to 9 years. One year earlier, 5 heifers had been actively immunized against inhibin with a primary and two booster injections (immunized group) and the remaining 5 heifers were injected with a placebo and served as controls (control group). Oestrous cycles were synchronized by i.m. injection of $0.5 \mathrm{mg}$ prostaglandin $\mathrm{F}_{2 \alpha} \quad\left(\mathrm{PGF}_{2 \alpha}\right)$ analogue (Estrumate, Sumitomo Pharm., Osaka, Japan). Thereafter, all heifers received a single i.m. injection of $\mathrm{PGF}_{2 \alpha}$ on day 18 of each oestrous cycle during the experimental period. On day 9 of the second oestrous cycle (day $0=$ day of oestrus), the immunized group was injected intramuscularly with inhibin vaccine (recombinant ovine inhibin $\alpha$-subunit in oil emulsion, $125 \mu \mathrm{g} \mathrm{ml}^{-1}$ ) followed by 2 boosters injected on day 9 of the third and fourth oestrous cycles. The control group was injected with a placebo (Montanide 888 (SEPPIC, Paris, France): Marcol 52 (EPPIC, Sydney, Australia) adjuvant alone). During each oestrous cycle, blood samples were collected every $12 \mathrm{~h}$ starting 9 days after oestrus until the end of oestrous cycle for hormonal assay and on day 9 and day 18 for determination of inhibin antibody titres. Blood samples were collected by jugular venipuncture into heparinized tubes, plasma was separated and stored at $-40^{\circ} \mathrm{C}$ until assayed for hormones and inhibin antibody titres. Schematic representation of this protocol is shown in Fig. 1.

\section{Preparation of inhibin vaccine}

The $\alpha$-subunit of ovine inhibin produced in E. coli by the recombinant DNA method (Forage et al. 1987) was used as an immunogen. The immunization dose was $1 \mathrm{ml}$ of the immunogen $\left(125 \mu \mathrm{g} \mathrm{ml}^{-1}\right)$ in Montanide 888:Marcol 52 (1:9) each time.

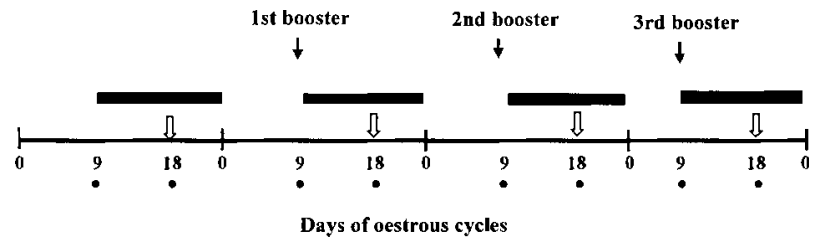

Figure 1 Schematic representation of the protocol used for re-immunization of heifers against inhibin. White arrows indicate time of $\mathrm{PGF}_{2 \alpha}$ injections, black rectangles indicate daily ultrasound examination and blood sampling every $12 \mathrm{~h}$ from day 9 to the end of each oestrous cycle for hormonal assay and • indicates a single blood sample on days 9 and 18 of each cycle for inhibin antibody titres.

\section{Determination of the ovarian response}

Ovarian follicular population and corpora lutea were determined daily from day 9 of each oestrous cycle until the end of oestrous cycle. Ultrasound scanner (SSD-650CL, Aloka, Tokyo, Japan) was used as described previously (Kaneko et al. 1991). Follicles were divided into three groups according to their diameter (small, $\geq 4<7$; medium, $\geq 7<10$ and large, $\geq 10 \mathrm{~mm}$ ). In these Japanese beef cattle, follicles larger than $10 \mathrm{~mm}$ in diameter were considered to be preovulatory follicles in the normal oestrous cycle (Kaneko et al. 1995a). Ovulation rate was confirmed by counting the number of corpora lutea by ultrasonography between days 7 and 9 after oestrus.

\section{Radioimmunoassays (RIAs)}

Plasma concentrations of $\mathrm{FSH}$ were measured by RIA as described previously (Bolt \& Rollins 1983) using anti-bovine FSH $\beta$ subunit antiserum (USDA-5-pool), USDA-FSH-BP3 for radioiodination and US Department of Agriculture (USDA)-FSH-B1 as a reference standard. Plasma concentrations of luteinizing hormone (LH) were measured by RIA (Echternkamp et al. 1976) using antiovine LH serum (USDA-309-684P), USDA-bLH-I-1 for radioiodination and USDA-bLH-B-1 as a reference standard. The intra- and inter-assay coefficients of variation were $6.0 \%$ and $11.5 \%$ for $\mathrm{LH}$ and $3.0 \%$ and $9.4 \%$ for $\mathrm{FSH}$, respectively.

Plasma concentrations of oestradiol-17 $\beta$ and progesterone were determined by a double antibody RIA system using ${ }^{125}$ I-labelled radioligands as described previously (Taya et al. 1985). Aliquots of $1 \mathrm{ml}$ plasma for oestradiol$17 \beta$ and $100 \mu \mathrm{l}$ for progesterone were extracted. Antisera against oestradiol-17 $\beta$ (GDN 244) and progesterone (GDN 337) were provided by Dr G D Niswender (Animal Production and Biotechnology, Colorado state University, Fort Collins, CO, USA). In oestradiol-17 assay, plasma samples were defatted with a mixture of $2 \mathrm{ml}$-hexane and $0.5 \mathrm{ml}$ acetonitrile to remove substances that could interfere with the estradiol-17 $\beta$ assay as described by Nagata et al. (1996). The intra- and inter-assay coefficients of variation were $4.2 \%$ and $9.5 \%$ for oestradiol- $17 \beta$ and $5.5 \%$ and $13.4 \%$ for progesterone, respectively.

Plasma inhibin antibody titres were determined as described by Kaneko et al. (1993a). Samples were diluted 1:12 with PBS containing 5\% (w/v) bovine serum albumin and incubated for $24 \mathrm{~h}$ at $32{ }^{\circ} \mathrm{C}$ with ${ }^{125} \mathrm{I}$-labelled bovine 32 KDa inhibin (5000 c.p.m. tube ${ }^{-1}$ ) in a total volume of $300 \mu \mathrm{l}$. Bound tracer was then separated by adding $100 \mu \mathrm{l}$ PBS containing $1 \%(\mathrm{w} / \mathrm{v})$ bovine $\gamma$-globulin and $500 \mu \mathrm{l}$ PBS containing $25 \%(\mathrm{w} / \mathrm{v})$ polyethylene glycol. The precipitate was counted following centrifugation at $1700 \mathrm{~g}$ for $30 \mathrm{~min}$. Inhibin-binding capacity was expressed as a percentage of the total counts added. 


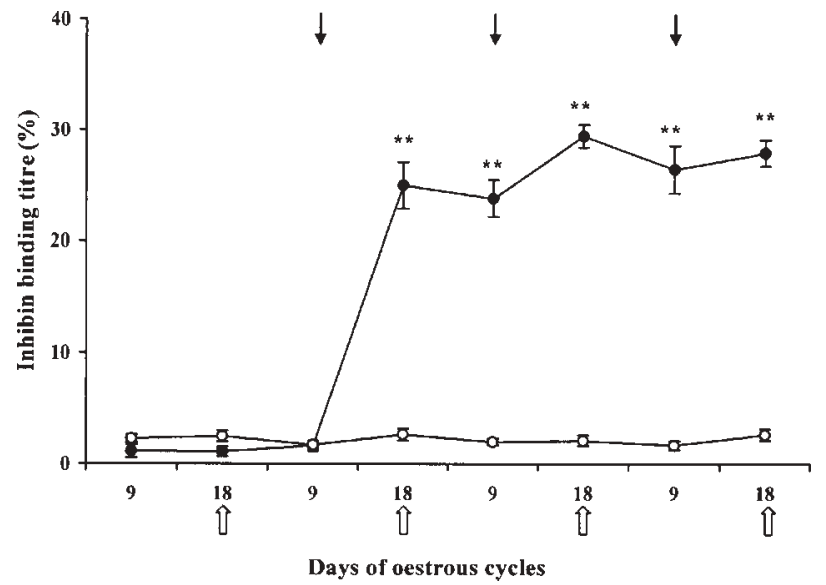

Figure 2 Plasma levels of inhibin antibody titres (\% binding of ${ }^{125}$ I-labelled bovine inhibin at 1:12 dilution of plasma) in inhibin reimmunized ( $\bullet$ ) and control (०) heifers measured at days 9 and 18 of each oestrous cycle. Values are mean \pm S.E.M. $(n=5)$. Black arrows indicate time of immunization and white arrows indicate time of $\mathrm{PGF}_{2 \alpha}$ injection. $* * P<0.01$ compared with respective control value.

\section{Statistical analysis}

All values shown are mean \pm S.E.M. ANOVA of repeated measures was used to examine the effect of inhibin immunizations on hormone levels and the number of follicles and corpora lutea. The significance of the difference between two means was determined by Students's $t$-test. A probability value $(P)$ of less than 0.05 was considered to be significant. All statistical analyses were performed using the SAS computer package (SAS 1987).

\section{Results}

\section{Inhibin antibody titres}

As shown in Fig. 2, immunized animals showed a rapid increase in inhibin antibody titres, reaching a peak level 9 days after the first booster injection and remained at the peak level during the second and third injections of inhibin vaccine. On the other hand, the inhibin antibody titres in controls were consistently at nonspecific
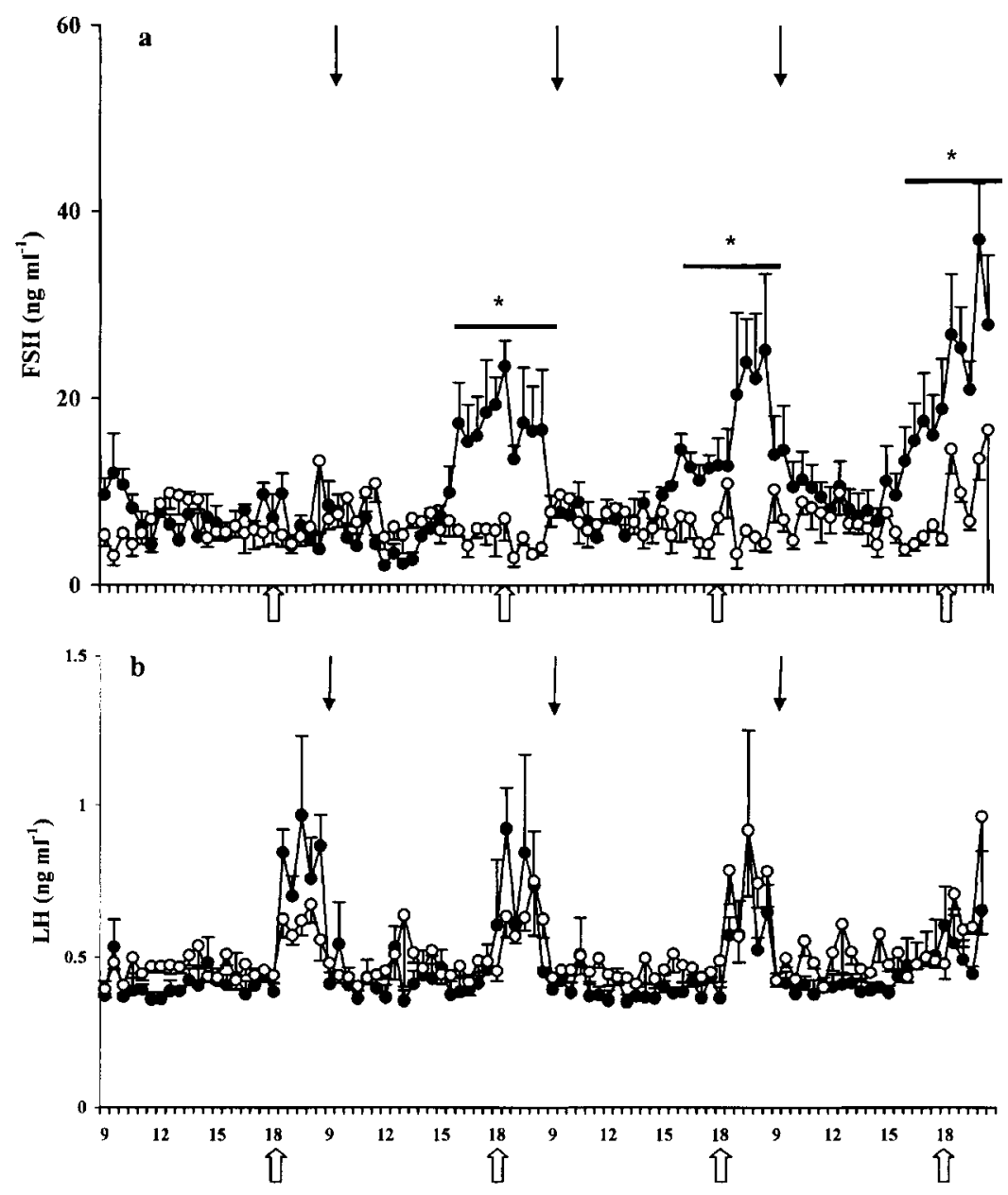

Days of oestrous cycles
Figure 3 Plasma concentrations of $\mathrm{FSH}$ (a) and $\mathrm{LH}$ (b) in inhibin re-immunized $(\bullet ; n=5)$ and control $(\circ ; n=5)$ heifers during 4 successive oestrous cycles. Black arrows indicate time of immunization and white arrows indicate time of $\mathrm{PGF}_{2 \alpha}$ injection. Values are mean \pm S.E.M. Values under the horizontal bars are significantly different from corresponding values in control group. $* P<0.05$. 
binding values, as before the injection of placebo. Inhibin antibody titres were significantly higher compared with controls starting 9 days after the first booster injection until the end of the experiment.

\section{Plasma concentrations of FSH and $\mathrm{LH}$}

Plasma concentrations of $\mathrm{FSH}$ and $\mathrm{LH}$ are shown in Fig. 3. There was no significant difference between the two groups before immunizations. About one week after first, second and third booster injections of inhibin vaccine the plasma concentrations of FSH showed a significant increase compared with controls. In contrast to $\mathrm{FSH}$, plasma concentrations of $\mathrm{LH}$ did not differ significantly between inhibin-immunized and control groups.

\section{Plasma concentrations of oestradiol-17 $\beta$ and progesterone}

Plasma concentrations of oestradiol- $17 \beta$ rose sharply after injection of $\mathrm{PGF}_{2 \alpha}$. There was 3- or 4-fold increase in plasma concentrations of oestradiol-17 $\beta$ after injection of inhibin vaccine compared with controls (Fig. 4a). Plasma concentrations of progesterone showed an abrupt decline after injection of $\mathrm{PGF}_{2 \alpha}$. In immunized heifers, there was a significant elevation in progesterone levels during the third and 4th oestrous cycles compared with control heifers (Fig. 4b).

\section{Ovarian activity and ovulation rate}

After injection of $\mathrm{PGF}_{2 \alpha}$, all animals exhibited oestrus. The interval from $\mathrm{PGF}_{2 \alpha}$ injection to the onset of pre-immunization oestrus was $85.8 \pm 8.1 \mathrm{~h}$ and $78.4 \pm 10.9 \mathrm{~h}$ in immunized and control groups, respectively. However, the overall mean interval from $\mathrm{PGF}_{2 \alpha}$ injection to oestrus was shorter in the immunized group $(58.3 \pm 7.9 \mathrm{~h})$ than in the control group $(77.1 \pm 5.5 \mathrm{~h})$ during the three successive oestrous cycles following inhibin immunization. In addition, the numbers of follicles in immunized and control animals are shown in Fig. 5. In comparison with controls, inhibin immunized heifers had significantly more follicles. Small sized follicles increased earlier than the other categories after the first booster injection. All categories of follicles were significantly higher after the second and third booster injections of inhibin vaccine compared with controls. Ovulation rate during the four successive oestrous cycles is shown in Fig. 6. In contrast to pre-immunization, there was a significant increase in the ovulation rate in immunized heifers after the injection of first, second and third boosters of inhibin vaccine in comparison with control group (single ovulation).

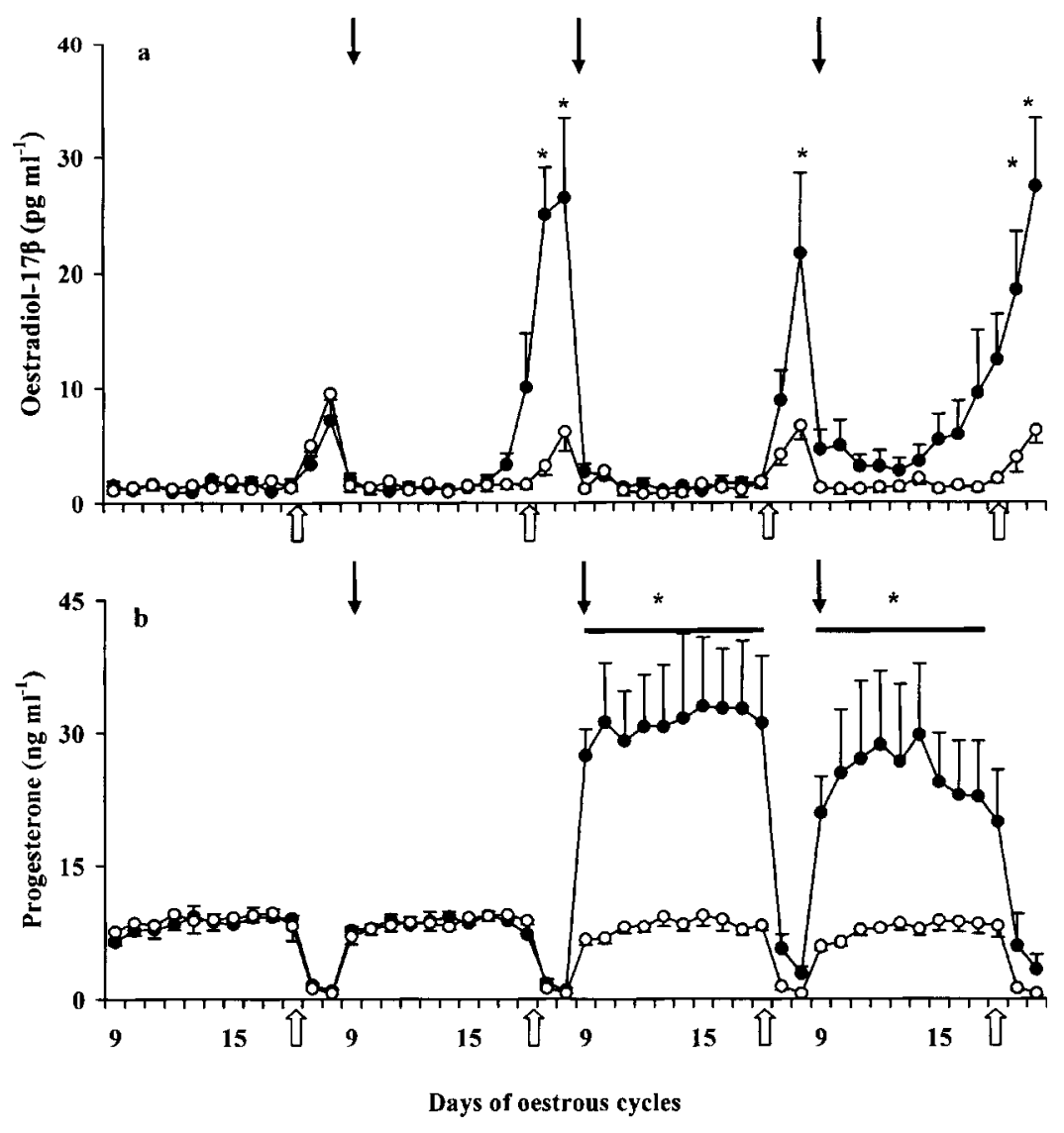

Reproduction (2004) 128 475-482
Figure 4 Plasma concentrations of oestradiol-17 $\beta$ (a) and progesterone (b) in inhibin re-immunized $(\bullet ; n=5)$ and control (o; $n=5$ ) heifers during 4 successive oestrous cycles. Black arrows indicate time of immunization and white arrows indicate time of $\mathrm{PGF}_{2 \alpha}$ injection. Values are mean \pm S.E.M. $* P<0.05$ compared with respective control value. 

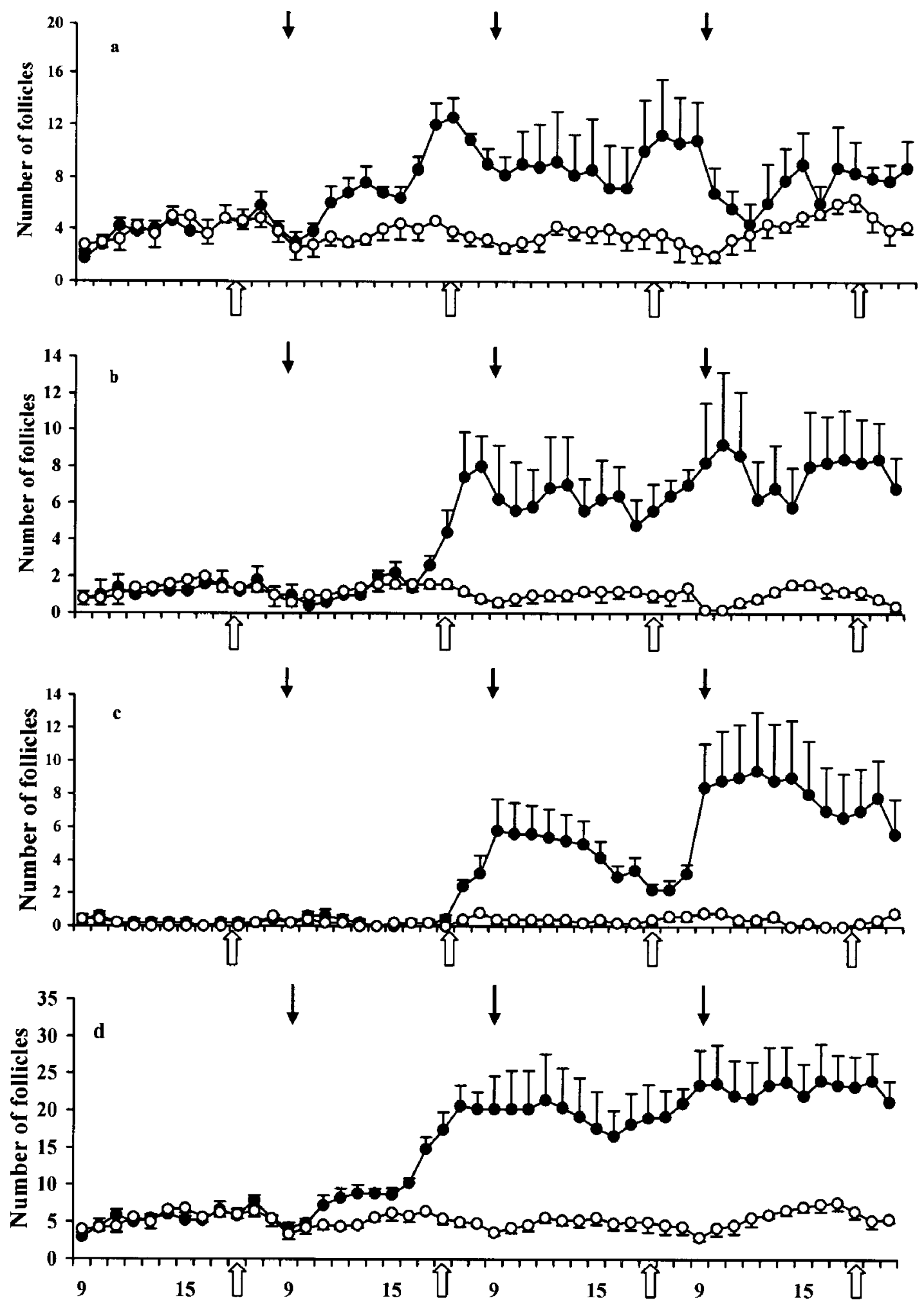

Days of oestrous cycle

Figure 5 Number of (a) small follicles, $\geq 4<7 \mathrm{~mm}$ in diameter; (b) medium follicles, $\geq 7<10 \mathrm{~mm}$ in diameter; (c) large follicles, $\geq 10 \mathrm{~mm}$ in diameter and (d) total follicles in inhibin re-immunized $(\bullet ; n=5)$ and control $(0 ; n=5)$ heifers during 4 successive oestrous cycles. Black arrows indicate time of immunization and white arrows indicate time of $\mathrm{PGF}_{2 \alpha}$ injection. Values are mean \pm S.E.M. 


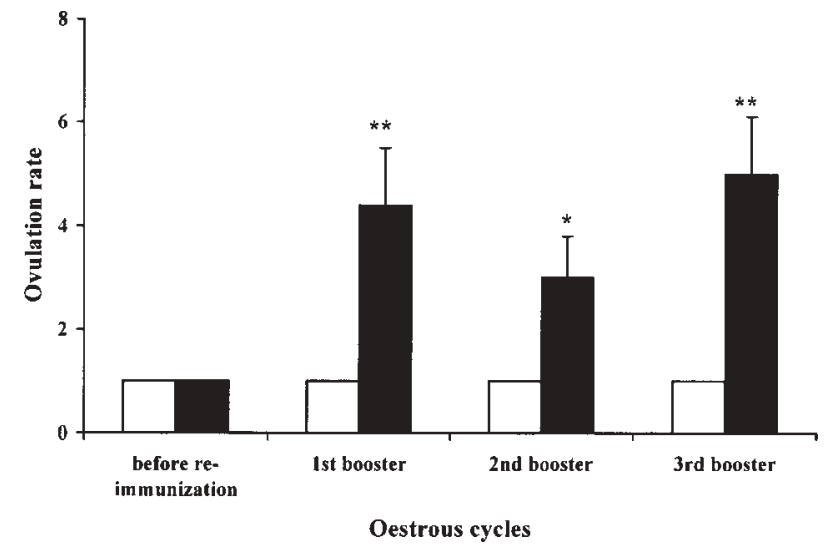

Figure 6 The mean ovulation rate in inhibin re-immunized (solid bar; $n=5$ ) and control (open bar; $n=5$ ) heifers before and after injection of inhibin vaccine or placebo. Values are mean \pm S.E.M. $* P<0.05$; $* * P<0.01$ compared with control value.

\section{Discussion}

This study clearly demonstrated the efficiency of re-immunization against inhibin in increasing the number of follicles and ovulation rate in heifers, which is associated with elevated plasma concentrations of FSH. Re-immunization of Japanese beef heifers against inhibin one year after the first immunization rapidly stimulated an immune response and all immunized heifers generated antibodies that bound ${ }^{125}$ I-labelled inhibin. Antibody binding was significant, confirming that increased ovulation rate after immunization with inhibin vaccine was due to immunoneutralization of endogenous inhibin. Immunoneutralization of endogenous inhibin diminished negative feedback on the anterior pituitary gland resulting in increased $\mathrm{FSH}$ secretion, subsequently increased follicular development and ovulation rate. There was a discrepancy in the previous studies about the effect of active immunization against inhibin on FSH secretions. Some reports (Findlay et al. 1989, Brown et al. 1990, Mizumachi et al. 1990, Wrathall et al. 1992, Medan et al. 2003b) demonstrated that active immunization against inhibin increased FSH secretions, meanwhile others (Schanbacher et al. 1991, Tannetta et al. 1998, Hennies et al. 2001) found an increase in ovulation rate without an increase in $\mathrm{FSH}$ levels. In the present study, we found that re-immunization against inhibin clearly increased FSH secretions. These findings suggest that inhibin may have local auto/ paracrine effects within the ovary and neutralization of one of these effects may augment FSH in enhancing follicular growth. In sheep, active immunization against inhibin increased intrafollicular activin A, unaccompanied by a rise in the concentration of its binding protein (follistatin) which, in turn, might enhance follicular growth and ovulation rate (Tannetta et al. 1998). In contrast to the observed increase in FSH concentrations following re-immunization against inhibin, concentrations of $\mathrm{LH}$ did not show a significant difference between inhibin vaccinated and control heifers in the present study.

The higher level of plasma oestradiol-17 $\beta$ in immunized heifers in the present study is probably due to an increased number of oestrogenic follicles destined to ovulate. Similarly, goats actively immunized against inhibin showed a significant increase in circulating oestradiol concentrations (Hennies et al. 2001, Medan et al. 2003b). In addition, the elevated plasma progesterone levels in inhibin re-immunized heifers reflects the increased ovulation rate and increased number of corpora lutea.

Multiple ovulations have been induced successfully by passive and active immunization against endogenous inhibin in domestic animals (Wheaton et al. 1992, 1996, Konishi et al. 1996, Akagi et al. 1997, Takedomi et al. 1997, Nambo et al. 1998, Medan et al. 2003a,b) and laboratory animals (Rivier \& Vale 1989, Kishi et al. 1996, Shi et al. 2000, Wang et al. 2001). In the present study, ovulation rate increased in re-immunized heifers after the first, second and third booster injections of inhibin vaccine, indicating that repeated injection of inhibin vaccine can be used for inducing superovulation without any adverse effect on ovulation rate. Moreover, the great number of medium and large sized follicles recorded in heifers injected with inhibin vaccine is a potential source for oocytes necessary for in vitro and embryo transfer programs. This may help in the production of cloned or transgenic cattle and the establishment of oocyte banks for superior breeds, especially with the availability of transvaginal ultrasound-guided follicular aspiration, which proved to be a non-stressful technique for repeated harvesting of oocytes from cows (Chastant-Millard et al. 2003).

In summary, re-immunization of cows with inhibin vaccine produced antibodies that neutralized endogenous inhibin and increased circulating FSH. In addition, the great number of follicles and increased ovulation rate indicate that inhibin immunization can be used repeatedly for induction of superovulation without any additional injections of exogenous gonadotrophins. Therefore, this study confirms that inhibin vaccine is a practical and repeatable method for promoting superovulation in heifers and that great number of follicles could be aspirated and used for in vitro fertilization and embryo transfer programs.

\section{Acknowledgements}

We are grateful to D J Bolt (USDA, Beltsville, MD, USA) for providing RIA materials for bovine FSH and LH, G D Niswender (Animal Reproduction and Biotechnology Laboratory, Colorado State University, Fort Collins, CO, USA) for providing antisera to oestradiol-17 $\beta$ (GDN 244) and progesterone (GDN 337). This work was supported in part by the Ito Foundation and the Japan Livestock Technology Association, a Grant-in-Aid for Scientific Research (The 21st Century Center of Excellence Program, E-1) from the Ministry of Education, Culture, Sports, Science and Technology of Japan and a 
Grant-in-Aid for Scientific Research (No. 03338) from the Japanese Society for the Promotion of Science.

\section{References}

Akagi S, Kaneko H, Nakanishi Y, Takedomi T, Watanabe G \& Taya K 1997 Ovarian response and FSH profile in cows following injection of various doses of inhibin antiserum. Journal of Veterinary Medical Science 59 1129-1135.

Akagi S, Shi F, Kaneko H, Watanabe G, Tsonis CG \& Taya K 2002 Ovarian response and hormonal profiles in heifers after immunization and re-immunization against inhibin $\alpha$-subunit. Journal of Reproduction and Development 48 599-605.

Araki K, Arai KY, Watanabe G \& Taya K 2000 Involvement of inhibin in the regulation of follicle-stimulating hormone secretion in the young adult male Shiba goat. Journal of Andrology 21 558-565.

Bavister BD, Dees C \& Schultz RD 1986 Refractoriness of rhesus monkeys to repeated ovarian stimulation by exogenous gonadotrophins is caused by nonprecipitating antibodies. American Journal of Reproductive Immunology and Microbiology 11 11-16.

Beard AJ, Castillo RJ, McLeod BJ, Glencross RG \& Knight PG 1990 Comparison of the effects of crude and highly purified bovine inhibin $(\mathrm{Mr} 32,000)$ on plasma concentrations of $\mathrm{FSH}$ and $\mathrm{LH}$ in chronically ovariectomized prepubertal heifers. Journal of Endocrinology 125 21-30.

Bolt DJ \& Rollins R 1983 Development and application of a radioimmunoassay for bovine follicle-stimulating hormone. Journal of Animal Science $\mathbf{5 6}$ 146-154.

Brown RW, Hungerford JW, Greenwood PE, Bloor RJ, Evans DF, Tsonis CG \& Forage RG 1990 Immunization against recombinant bovine inhibin alpha subunit causes increased ovulation rates in gilts. Journal of Reproduction and Fertility 90 199-205.

Campbell BK \& Scaramuzzi RJ 1995 Effect of acute immunoneutralization of inhibin in ewes during the late luteal phase of the oestrous cycle on ovarian hormone secretion and follicular development during the subsequent follicular phase. Journal of Reproduction and Fertility 104 337-345.

Chastant-Maillard S, Quinton H, Lauffenburger J, Cordonnier-Lefort N, Richard C, Marchal J, Mormede P \& Renard JP 2003 Consequences of transvaginal follicular puncture on well-being in cows. Reproduction 125 555-563.

Echternkamp SE, Bolt DJ \& Hawk HW 1976 Ovarian and pituitary hormones in blood of progestogen-treated ewes. Journal of Animal Science 42 893-900.

Findlay JK, Doughton B, Robertson DM \& Forage RG 1989 Effects of immunization against recombinant bovine inhibin alpha subunit on circulating concentrations of gonadotrophins in ewes. Journal of Endocrinology 120 59-65.

Forage RG, Brown RW, Oliver KJ, Atrache BT, Devine PL, Hudson GC, Goss NH, Bertram KC, Tolstoshev P, Robertson DM, Doughton B, Burger HG \& Findlay JK 1987 Immunization against an inhibin subunit produced by recombinant DNA techniques results in increased ovulation rate in sheep. Journal of Endocrinology 114 R1-R4.

Fray MD, Wrathall JH \& Knight PG 1994 Active immunisation against inhibin promotes a recurrent increase in litter size in sheep. Veterinary Record 134 19-20.

Glencross RG, Bleach EC, Wood SC \& Knight PG 1994 Active immunization of heifers against inhibin: effects on plasma concentrations of gonadotrophins, steroids and ovarian follicular dynamics during prostaglandin-synchronized cycles. Journal of Reproduction and Fertility 100 599-605.

Hennies M, Voglmayr JK, Dietrich E, Stollmann M, Moeller R \& Holtz W 2001 Hormonal response of female goats to active immunization against a recombinant human inhibin $\alpha$-subunit, and establishment of an enzyme-linked immunosorbent assay for caprine follicle-stimulating hormone. Reproduction in Domestic Animal 36 65-71.
Kaneko H, Terada T, Taya K, Watanabe G, Sasamoto S, Hasegawa Y \& Igarashi M 1991 Ovarian follicular dynamics and concentrations of oestradiol-17 beta, progesterone, luteinizing hormone and follicle stimulating hormone during the periovulatory phase of the oestrous cycle in the cow. Reproduction Fertility and Development $3529-535$.

Kaneko H, Nakanishi Y, Taya K, Kishi H, Watanabe G, Sasamoto S \& Hasegawa Y 1993a Evidence that inhibin is an important factor in the regulation of FSH secretion during the mid-luteal phase in cows. Journal of Endocrinology 136 35-41.

Kaneko H, Yoshida M, Hara Y, Taya K, Araki K, Watanabe G, Sasamoto S \& Hasegawa Y $1993 b$ Involvement of inhibin in the regulation of FSH secretion in prepubertal bulls. Journal of Endocrinology 137 15-19.

Kaneko H, Kishi H, Watanabe G, Taya K, Sasamoto S \& Hasegawa Y 1995a Changes in plasma concentrations of immunoreactive inhibin, oestradiol and FSH associated with follicular waves during the oestrous cycle of the cow. Journal of Reproduction and Development 41 311-320.

Kaneko H, Nakanishi Y, Akagi S, Arai K, Taya K, Watanabe G, Sasamoto S \& Hasegawa Y 1995 b Immunoneutralization of inhibin and oestradiol during the follicular phase of the oestrous cycle in cows. Biology of Reproduction 53 931-939.

Kishi H, Okada T, Otsuka M, Watanabe G, Taya K \& Sasamoto S 1996 Induction of superovulation by immunoneutralization of endogenous inhibin through the increase in the secretion of follicle stimulating hormone in the cyclic golden hamster. Journal of Endocrinology 151 65-75.

Kishi H, Okada T, Kawazu S, Otsuka M, Taya K, Watanabe G \& Sasamoto S 1997 Effects of passive immunization against oestradiol-17 $\beta$ and inhibin on the secretion of gonadotrophin in the cyclic golden hamster (Mesocricetus auratus). Reproduction, Fertility and Development 9 447-453.

Konishi M, Aoyagi Y, Takedomi T, Itakura H, Itoh T, Yazawa S, Kishi H, Taya K, Watanabe G \& Kanagawa H 1996 Effect of active immunization of cattle against inhibin on ovarian follicular development and ultrasound-guided transvaginal follicular aspiration. Theriogenology 46 33-43.

Kusina NT, Meyer RL, Carlson KM \& Wheaton JE 1995 Passive immunization of ewes against an inhibin like peptide increases follicle-stimulating hormone concentrations, ovulation rate and prolificacy in spring-mated ewes. Journal of Animal Science $\mathbf{7 3}$ 1433-1439.

Medan MS, Watanabe G, Sasaki K, Nagura Y, Sakaime H, Fujita M, Sharawy S \& Taya K 2003a Effects of passive immunization of goats against inhibin on follicular development, hormone profile and ovulation rate. Reproduction 125 751-757.

Medan MS, Watanabe G, Sasaki K, Nagura Y, Sakaime H, Fujita M, Sharawy S \& Taya K 2003b Ovarian and hormonal response of female goats to active immunization against inhibin. Journal of Endocrinology 177 287-294.

Mizumachi M, Voglmayer JK, Washington DW, Chen CL \& Bardin CW 1990 Superovulation of ewes immunized against the human recombinant inhibin $\alpha$-subunit associated with increased pre and postovulatory follicle-stimulating hormone levels. Endocrinology 126 1058-1063.

Nagata S, Kondou M, Kaneko H, Araki K, Nambo Y, Oikawa M, Watanabe G \& Taya K 1996 A simple defatting method using a partition method of acetonitrile and $n$-hexane for radioimmunoassay of low blood levels of oestradiol-17ß. Journal of Reproduction and Development 42 j43-j49.

Nambo Y, Kaneko H, Nagata S, Oikawa M, Yoshihara T, Nagamine N, Watanabe G \& Taya K 1998 Effect of passive immunization against inhibin on FSH secretion, folliculogenesis and ovulation rate during the follicular phase of the oestrous cycle in mares. Theriogenology 50 545-557.

Ramaswamy S, Pohl CR, McNeilly AS, Winters SJ \& Plant TM 1998 The time course of follicle-stimulating hormone suppression by 
recombinant human inhibin $\mathrm{A}$ in the adult male rhesus monkey (Macaca mulatta). Endocrinology 139 3409-3415.

Rivier C \& Vale W 1989 Immunization of endogenous inhibin modifies hormone secretion and ovulation rate in the rat. Endocrinology $125152-157$.

Roy F, Maurel M, Combes B, Vaiman D, Cribiu E, Lantier I, Pobel T, Deletang F, Combarnous Y \& Guillou F 1999 The negative effect of repeated equine chorionic gonadotrophin treatment on subsequent fertility in Alpine goats is due to a humoral immune response involving the major histocompatibility complex. Biology of Reproduction 60 805-813.

SAS 1987 Statistics, version 6.11. Cary, NC, USA: SAS Institute Inc.

Schanbacher BD, Schemm SR \& Rhind SM 1991 Gonadotrophin concentrations and ovulation rates in Suffolk ewes actively or passively immunized against inhibin alpha. Journal of Reproduction and Fertility 93 133-139.

Shi F, Mochida K, Suzuki O, Mateuda J, Ogura A, Ozawa M, Watanabe G, Suzuki A \& Taya K 2000 Ovarian localization of immunoglobulin $G$ and inhibin $\alpha$-subunit in guinea pigs after passive immunization against the inhibin $\alpha$ subunit. Journal of Reproduction and Development 46 293-299.

Swanson WF, Horohov DW \& Godke RA 1995 Production of exogenous gonadotrophin-neutralizing immunoglobulins in cats after repeated eCG-hCG treatment and relevance for assisted reproduction in felids. Journal of Reproduction and Fertililty 105 35-41.

Takedomi T, Kaneko H, Aoyagi Y, Konishi K, Kishi H, Watanabe G \& Taya K 1997 Effects of passive immunization against inhibin on ovulation rate and embryo recovery in Holstein heifers. Theriogenology $471507-1518$.

Tannetta DS, Feist SA, Bleach ECL, Groome NP, Evans LW \& Knight PG 1998 Effects of active immunization of sheep against an amino terminal peptide of the inhibin alphaC subunit on intrafollicular levels of activin A, inhibin A and follistatin. Journal of Endocrinology $157157-168$.
Taya K, Watanabe G \& Sasamoto S 1985 Radioimmunoassay for progesterone, testosterone and oestradiol $17 \beta$ using ${ }^{125}$ I-iodohistamine radioligands. Japanese Journal of Animal Reproduction 31 186-197.

Tilbrook AJ, De Kretser DM \& Clarke IJ 1993 Human recombinant inhibin A suppresses plasma follicle-stimulating hormone to intact levels but has no effect on luteinizing hormone in castrated rams. Biology of Reproduction 49 779-788.

Wang H, Herath CB, Xia G, Watanabe G \& Taya K 2001 Superovulation, fertilization and in vitro embryo development in mice after administration of an inhibin-neutralizing antiserum. Reproduction 122 809-816.

Wheaton JE, Carlson KM \& Kusina NT 1992 Active and passive immunoneutralization of inhibin increases follicle-stimulating hormone levels and ovulation rate in ewes. Biology of Reproduction $47361-367$.

Wheaton JE, Thomas DL, Kusina T, Gottfrendson RG \& Meyer RL 1996 Effects of passive immunization against inhibin-peptide on secretion of follicle-stimulating hormone and ovulation rate in ewes carrying the Booroola fecundity gene. Biology of Reproduction $551351-1355$.

Wrathall JHM, McLeod BJ, Glencross RG \& Knight PG 1992 Effects of active immunization against a synthetic peptide sequence of the inhibin $\alpha$-subunit on plasma gonadotrophin concentrations, ovulation rate and lambing rate in ewes. Journal of Reproduction and Fertility 95 175-182.

Received 13 March 2004

First decision 11 June 2004

Accepted 1 July 2004 